\title{
338 細胞外基質の変形に伴う移動性細胞の移動方向変化
}

Change in crawling direction of fish keratocytes induced by substrate deformation

\author{
○正 田原 大輔（理研） \\ 正 安達 泰治 (理研, 京都大)
}

Daisuke TAWARA Computational Cell Biomechanics Team, VCAD System Research Program, RIKEN, Yoshida-honmachi, Sakyo-ku, Kyoto Taiji ADACHI Department of Mechanical Engineering and Science, Kyoto University, Yoshida-honmachi, Sakyo-ku, Kyoto

Key Words: Cellular biomechanics, Keratocyte, Cell migration, Substrate deformation, Micropatterned substrate

\section{1. 緒 言}

高い運動性を示す移動性細胞のケラトサイド(1)は, 周囲の環 境変化を感知し, 自らの内部構造や特性を変化させながら, 能 動的に前進し ${ }^{(2)}$, 移動方向を変化させる. 特に移動方向の変 化には, 細胞内部のアクチンフィラメントの重合と脱重合, 膜や 細胞骨格に作用する力のバランス, 細胞外基質との接着強度 等が大きく影響を与える( ${ }^{(3)} と$ 考えられる. 筆者らはこれまでに, 紐胞内のアクチン瀻維が, 作用する張力の解放により, 脱重合 と再構築を開始することを示した ${ }^{(4)}$. また, マイクロパターニング 技術 ${ }^{(5)}$ を用いた細胞接着領域の制限により，細胞がパターンに 依存して配向し、アクチン骨格の形成が促進されることを観察し た (6).さらに, ケラトサイトに対して圧縮変形を与えると, 細胞の 移動方向が, 圧縮軸に平行な方向一変化することを示した ${ }^{(7)}$.

本研究では, 焦点接着斑のパターン制御下における細胞外 基質の変形が, ケラトサイトの移動方向変化に与える影響を検 討するため, まず, フィブロネクチンのマイクロパターニングを用 い, パターン上のケラトサイトの移動方向を評価した. 次に, 伸 縮可能なシリコーン膜にパターンを施して細胞を播種した後, 細胞外基質の変形を与え, 細胞の移動方向変化をパターン制 御の有無で経時的に観察した。

\section{2. 観察材料の作成方法および実験方法}

本実験では，まず，接着斑の分布制御がケラトサイトの移動 方向に与える影響を検討するため, ガラスベースディッシュ上で, 細胞接着因子であるフィブロネクチンのパターンの有無による 細胞の配向性を比較する. 次に, 接着斑の分布制御下で, 細 胞外基質の変形による細胞の移動方向変化を評価するため, 4 cc シリコーンチャンバー(スカラテック)膜にフィブロネクチンのパ

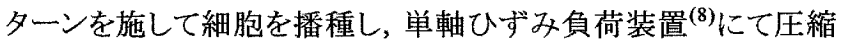
変形を与えた後, 経時的に細胞の移動方向変化を観察する.

$2 \cdot 1$ 細胞培養の条件本実験では, ゼブラフィッシュより単 離したケラトサイトを用いた. まず, ゼブラフイッシュの鱗を2枚採 取し, 直径 $35 \mathrm{~mm}$ のガラスボトムディッシュに静置した.この状 態で, $55 \%$ 濃度に希䣋した DMEM にFBS $20 \%$ と抗生物質 (ampicillin $12.8 \mathrm{mg} / \mathrm{ml}$, streptomycin $40 \mathrm{mg} / \mathrm{ml}$ ) を添加した培 地を用いて, 12 時間室温にて培養した.この間, ケラトサイトが 鱗からディッシュ上に移動し, その底面に接着する. 実験には, ケラトサイトを Trypsin/EDTA により剥離し, ガラスベースディッ シュと, シリコーン膜にそれぞれ播種したものを用いた。

$2 \cdot 2$ マイクロパターンの作成＼cjkstart本実験では, マイクロパター ンの作成のために, PDMS (Poly-dimethyl-siloxane) -stampを用 いた. パターンの作成概要と形状を Fig.1 に示す.ここでは, 10

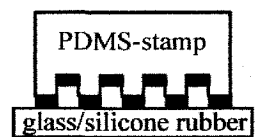

(1) Put stamp on a dish/chamber

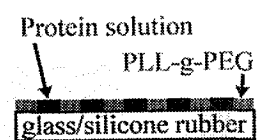

(2) Backfill with PLL-g-PEG

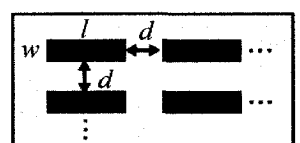

Stamped surface $(l=10 \mu \mathrm{m}$, $w=1.5 \mu \mathrm{m}, d=4.0 \mu \mathrm{m})$
Fig. 1 Procedure of fibrobectin micro-pattering $\mu \mathrm{m} \times 1.5 \mu \mathrm{m}$ の長方形が, $4.0 \mu \mathrm{m}$ の間隔で並んだスタンプを使 用した。これを用いて, $25 \mu \mathrm{g} / \mathrm{ml}$ のフィブロネクチンとFibrinogen Alexa 546 conjugate $の$ 混合液 (Protein Solution)をスタンプする ことで, 長方形の細胞接着領域が形成され, パターンの蛍光観 察が可能となる. スタンプの前に, まず, $\mathrm{pH} 3$ の希塩酸で $10 \%$ 濃度に希釈した cell matrix(新田ゼラチン)でディッシュとシリ コーン膜の表面をコーティングした. スタンプ後, 接着斑の形成 阻害剤である Poly-L-Lysine-graft-Poly Ethylene Glycol (PLLg-PEG, $1 \mathrm{mg} / \mathrm{ml}$ in 10mM Hepes buffer)をコーティングし, スタ ンプした部分のみを細胞接着領域とした.なお, シリコーン膜へ のパターンの作成においては, 長方形パターンの長手方向が, チャンバーの単軸圧縮変形負荷方向と同じになるようにした.

$2 \cdot 3$ 実験方法細胞一の変形負荷は, 細胞を播種し, 90 分間接着を待った後に行った.シリコーン膜に対して,ひずみ 速度 $-0.036 / \mathrm{sec}$.で単軸圧縮ひずみ $\varepsilon=-0.25$ を与えた後, 時間 経過ごとに, $3 \%$ パラホルムアルデヒドを用いて細胞を固定した. その後，1\% Triton-X による脱膜処理をし, Alexa488Phalloidin でアクチンフィラメントを蛍光染色した. 各実験で 150 個以上の細胞を対象とし, 共焦点レーザー走查型蛍光顕微鏡 (Nikon Digital Eclipse C1)を用いて観察を行った。

2.4 画像解析 観察画像は, 画像解析ソフト Image-J (NIH) を用いて解析した. 本研究では，ケラトサイトの外形状を相当棈 円で Fig.2(a)に示すように近似し，その短軸方向を移動方向之 して定義した. また, チャンバーの変形負荷直後を $t=0$ とし, 変 形負荷前 $(t<0)$, 直後 $(t=0)$, 負荷加 $t(0<\mathrm{t})$ 分後をそれぞ れ状態 I, II, III とする. 各状態における圧縮軸(長方形パタ一 ンの長手方向) と細胞の移動方向とのなす角度を $\theta_{i}(\mathbf{i}=\mathrm{I}, \mathrm{II}$, III, $\left.0^{\circ} \leq \theta_{\mathrm{i}} \leq 90^{\circ}\right)$ とすると, チャンバーの圧縮変形により生じる 幾何学的な角度変化 $\Delta \theta_{\mathrm{a}}\left(=\Delta \theta_{\mathrm{I}}-\Delta \theta_{\mathrm{I}}\right)$ は, 次式で与えられる.

$$
\Delta \theta_{\mathrm{a}}=\tan ^{-1}\left(\frac{-\varepsilon \sin \theta_{1} \cos \theta_{\mathrm{I}}}{1+\varepsilon \sin ^{2} \theta_{\mathrm{I}}}\right)
$$

なお, ポアソン効果により生じる圧縮軸に垂直な方向のひずみ を無視し，Fig.2(b)に示すように, 状態 I における点 A, B が, 生 縮軸に平行に移動して，それぞれ点 $\mathrm{A}^{\prime}$, $\mathrm{B}^{\prime}$ に移ると仮定した。

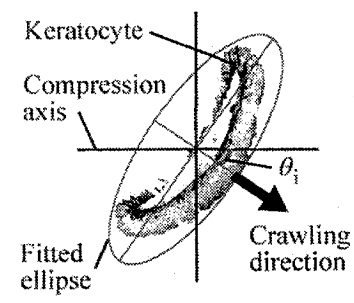

(a) Definition of crawling direction (b) Schematic of definition of $\theta_{\mathrm{l}}, \theta_{\mathrm{tI}}$ and calculation of $\Delta \theta_{\mathrm{a}}$

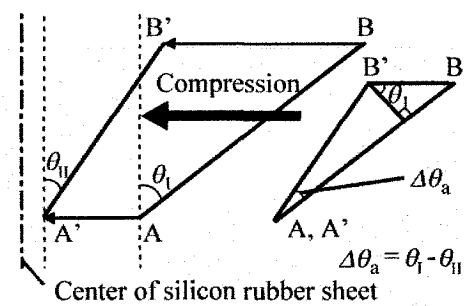

Fig.2 Definition of changes in crawling direction

\section{3. 実験結果}

ディッシュ上におうけるケラトサイトの $\theta_{1}$ 分布をパターンの有無 で比較して Fig.3 に示す. グラフは, 各角度の細胞数を細胞総

日本機械学会 [No.07-49]第 20 回バイオエンジニアリング講演論文集（'08-1.25〜26 東京） 


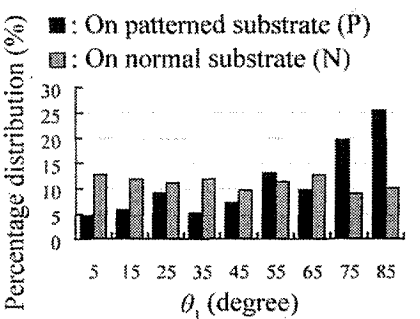

Fig.3 Cell orientaion of $\theta_{1}$ on patterned/normal glass dish

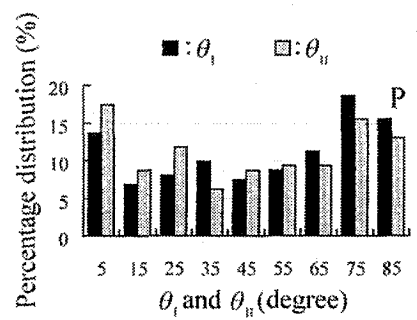

Fig. 4 Cell orientaion of $\theta_{1}$ and $\theta_{11}$ on patterned silicone rubber

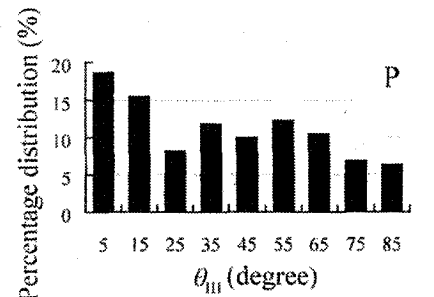

(a) $t=1 \mathrm{~min}$.

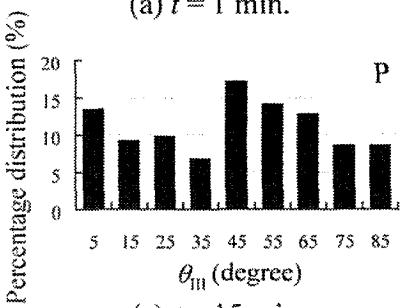

(c) $t=15 \mathrm{~min}$.

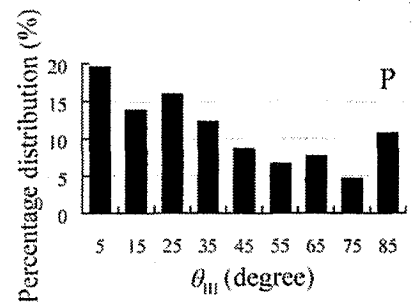

(b) $t=3 \mathrm{~min}$

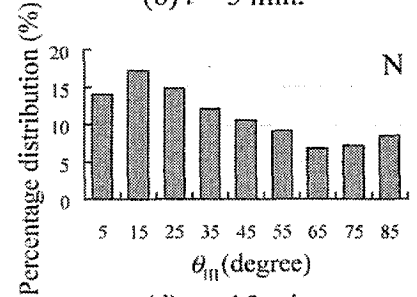

(d) $t=15 \mathrm{~min}$.

Fig. 5 Cell orientaion of $\theta_{\mathrm{II}}$ on patterned/normal silicone rubber

数で正規化して示した. 図より,パターン上では, 細胞の移動方 向が, パターンの長手方向に対して 50〜90に配向している. これに対し,パターンのない場合は, 細胞の配向性は見られな い.これらの結果から, ケラトサイトは, 長方形パターンの長手方 向に対して,垂直に移動する傾向がわかった.

次に，パターンを付したシリコーン膜上の細胞に拉ける $\theta_{1}$ と， その $\theta_{\mathrm{I}}$ から式(1)により計算される $\theta_{\text {II }}$ の分布を Fig.4 に示す. 図 より， $\theta_{1}$ は, ディッシュ上と同じように, パターンの長手方向に対 して, 垂直に配向する傾向 $\left(70^{\circ} \sim 90^{\circ}\right)$ が見られる. また, 状態 I から II 一遷移した時点では, 幾何学的な角度変化により, $0^{\circ}$ 〜30, $70^{\circ} \sim 90^{\circ}$ に細胞が配向することが予想される.

さらに, パターンを付したシリコーン膜上の細胞における $t=1$, $3,15 \mathrm{~min}$, およびパターンを付さない場合の $t=15 \mathrm{~min} の \theta_{\mathrm{II}}$ 分 布を Fig.5(a)-(d)にそれぞれ示す. グラフより, $t=1 \min の \theta_{\mathrm{III}}$ 分 布は, Fig.4の $\theta_{\mathrm{II}}$ 分布と比べ, 長方形パターンの長手方向, す なわち, 圧縮変形方向 $\left(0^{\circ} \sim 30^{\circ}\right)$ 一と変化している(Fig.5(a)). また, $t=3 \mathrm{~min}$ では, 圧縮変形方向に対して, $0^{\circ} \sim 40^{\circ}$ の角度を な寸細胞がさらに増加し, $40^{\circ} \sim 80^{\circ}$ の角度をなす細胞が減少し ている(Fig.5(b)). しかし, $t=15 \mathrm{~min} に$ において, パターン上では, パターンの長手方向 (圧縮変形方向) に対して $0^{\circ} \sim 40^{\circ}$ の角度 をなす細胞が減少し, $40^{\circ} \sim 80^{\circ}$ の角度をなす細胞が増加してい る(Fig.5(c)).これに対して, パターンがない場合は, 圧縮変形 方向に対して平行 $\left(0^{\circ} \sim 40^{\circ}\right)$ のままの細胞が多く見られた (Fig.5(d)).これらの結果から, ケラトサイトの移動方向は, 圧縮 変形に対応して変形負荷方向へと変化寸るが, その後, 再び パターンに依存して変化することが示された。

\section{4. 考察}

ケラトサイトの運動の駆動力は, Fig.6 のように, 細胞体から葉 状仮足の先端へ伸びるアクチンフィラメントの重合が, 細胞膜を

押し出すことにより発生すると考えられている. また, 細胞体部 には，移動方向と直交するようにストレスファイバーが形成され， 接着斑を介して引張力が作用すると考えられる. 細胞の移動方 向は, これらのべクトルの合力に一致すると考えられる.

細胞の移動方向は, Fig.7 に示すように, 状態 I では, 長方 形パターンの長手方向 (圧縮変形方向)に対して垂直 (Fig.7 (a)）で, 状態 III では, 平行な向きへ変化した(Fig.7(b)). パター ン上には, 接着斑が高密度で分布すると予想されることから, 状 態 I の細胞の配向性は, 長方形パターンに平行なストレスファ イバーに結合する接着斑を介した引張力が強く作用した結果と 考えられる.しかし, 変形後の細胞は, パターンの長手方向と直 交する圧緶変形方向へ移動方向を変化させたことから, 細胞内 では, 変形前の駆動力および接着強度の均衡が崩れ, 合駆動 力の方向が, 圧縮変形方向一向いたと考えられる.

変形負荷時の細胞の向きにより, 細胞内の各部位における 変形量には違いが生じる. アクチン細胞骨格の動的安定性に は, 力学的な因子が影響を与えている ${ }^{(8)}$ こかから, 細胞内の変 形量が大きい領域では, アクチンフィラメントの脱重合と張力の 緩和が起こり, それに結合する接着斑の解体が促進されると推 定される.さらに, これらが, 駆動力を生み出すアクチンモノマー の重合の速度変化を引き起こし, 細胞全体におけるアクチン重 合速度分布に依存して, 細胞の移動方向が変化する可能性が 考えられる. 今後, 圧縮ひずみの負荷が, 細胞内のアクチンフィ ラメントの重合速度に与える影響について, 実験的に検証し, 細胞の移動方向の変化と合わせて検討することが必要である.

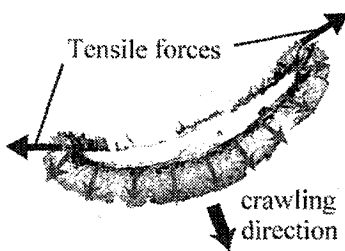

Fig.6 Hypothetical mechanism of change in crawling direction

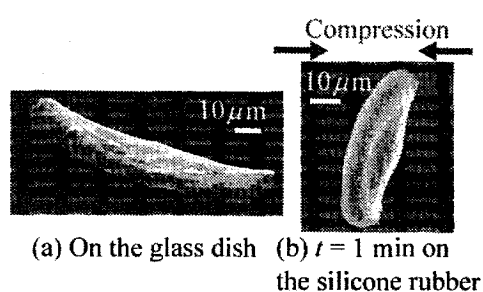

Fig.7 Fluorescence images of actin filament in the keratocytes

\section{5. 結 言}

焦点接着斑のパターン制御をした上で, 細胞外基質に変形 を与え,ケラトサイトの移動方向変化を経時観察した. その結果, ケラトサイトの移動方向は, 接着斑の制御に依存し, 圧縮変形 負荷に対応して, 圧縮軸に平行な方向一と変化することが示さ れた.さらに, 圧縮変形負荷後は, 再び接着斑の制御に依存し て移動方向を変化させることが示された.

本研究では, Boris Hinz 博士 (Swiss Federal Institute of Technology)に PDMS-stamp を提供いただいた. また, 須長純 子氏(理研)には実験に協力いただいた。記して，謝意を表す.

\section{参考文献}

(1) Svitkina TM, et al., J. Cell Biology, 139 (2), (1997), 397-415.

(2) Bray D, Cell Movements from Molecules to Motility 2nd edition, Garland Publishing, 2001.

(3) Verkhovsky AB, et al., Molecular Biology of the Cell, 14, (2003), 4667-4675.

(4) Sato $\mathrm{K}$, et al., $J$ Biomechanical Science and Engineering, 1 (1), (2006), 204-214

(5) Singhvi R, et al., Science, 264, (1994), 696-698.

(6) 田原大輔 ほ名, 機講論, 06-65, (2007), 118-119.

(7) 下川善道 ほか, 機講論, 04-39, (2004), 23-24.

(8) Sato K, et al., J. Biomechanics, 38, (2005), 1895-1901. 